\title{
Factors Affecting the Stress Relaxation of the Gluten-Water System
}

\author{
by
}

\author{
Sachio Matsumoto, Koji Katayama and Daizo Yonezawa \\ (College of Agriculture, University of Osaka Prefecture, Sakai, Osaka)
}

The stress relaxation behaviour of a gluten-water mixture, which was prepared by mixing the dried gluten protein with water in the weight ratio gluten: water $=1: 0.5$, was studied to simulate the properties of wheat flour dough. The rheological properties of wheat flour dough are complex ones, but it is believed that the gluten-water system is a good model for the continuous phase of the dough.

The results obtained can be summarized as follows:

(1) The gluten-water system shows linear viscoelastic response.

(2) The addition of a small amount of the reducing agent glutathione is effective in softening the system above a temperature of $20^{\circ} \mathrm{C}$; this suggests that an interchange reaction between -SH and -SS- in the gluten is induced at relatively high temperatures.

(3) Since the presence of an electrolyte also has an effect on the rheological properties of the system, one needs to use various salt concentrations to fully understand the phenomena involved. Future work will be directed toward studying the interaction mechanism between gluten protein and various electrolytes.

\section{グルテンタンパク質 - 水2成分系の応力緩和におよばす諸因子}

$$
\text { 松本 幸 雄*・片 山幸 二**米 沢大 造* }
$$

\section{（原稿受理 1974 年1月5日）}

\section{1 緒}

\section{言}

小麦粉の dough のレオロジ一的性質は，小麦粉を原料とする 食品の加工・調理における重要な特性の一つであるが，そのよう な性質におよぼす要因を明らかにするてとは，小麦の種類が多様 でその成分組成も複雄であるために容易ではない，本研究は，て の問題を解決するため一つの試みとして著者らが行なっている一 連の実験1,2) の一部をなすものである。すすおち，分散系である 小麦粉の dough の連続相部分を構成する主要な成分はグルテン タンパク質（以下グルテンと記す）と水であると考光られるので, dough の連続相のモデレとしてグルテンー水 2 成分系のゲルを 調製し、その応力緩和を種々の条件で観測した.

\section{2 実験}

\section{$2 \cdot 1$ 試}

$$
\text { 料 }
$$

小麦の主要な成分の一つであるグルテンは，その characterization に関する浜渦ら ${ }^{3)}$ の研究の結果にも示されているように,

\footnotetext{
* 大阪府立大学農学部 堺市百舌鳥梅町
}

分子量の異なる多数のポリペプチド成分がー S S-結合により集 合した襍雑なタンパク質である.しかし，小麦から分離されたグ ルテンを比較的少量の水と混ねつするてとにより，巨視的には均 一な状態の粘稠なゲルを調製するてとができる。

本実験に用いたグルテンは, 市販の未漂白小麦粉のうち強力粉 として格付けされているものから，既報19ように Jones ら ${ }^{1)} の$ 方法に準じて分離した。つぎ，その涷結乾燥物 1 部に対し，重 量比にして水 0.5 部を加え, 乳鉢で10分間混ねつして本実験の試 料とした，試料の調製は，測定の都度行なったが，その方法はど の試料についても上述のとおりである.

\section{$2 \cdot 2$ 応力緩和測定法}

本実験では，水銀上に浮かべた円柱状試料の長さ方向に一定の 伸びひずみを加え続けたとき, 陚料に生じる伸び応力の時間変化 から緩和弾性率（ヤング率）を求める方式のものを用いた，その 装置および測定方法の詳細は, 前報 ${ }^{2)}$ に記載したとおりである.

\section{3 結 果 と考 察}

\section{$3 \cdot 1$ 緩和弾性率の伸びひずみ依存性}

Fig. 1 亿示すように, 試料の弾性率は伸びひずみを加えてから 


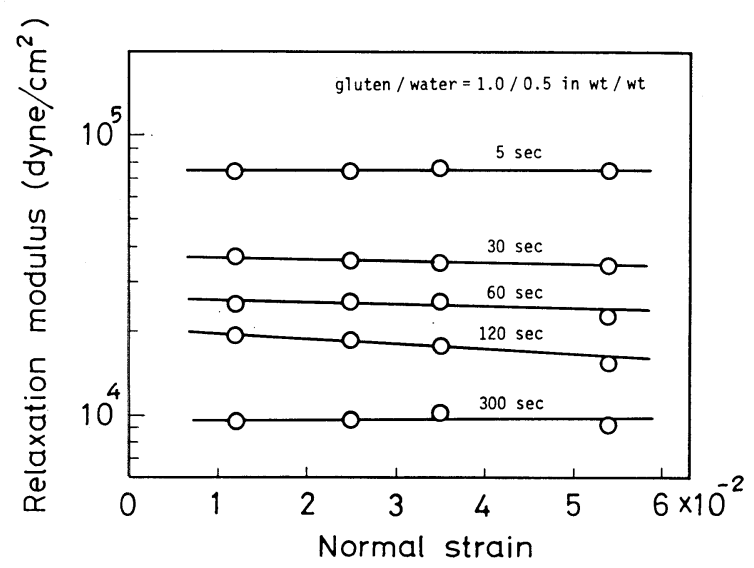

Fig. 1. Strain dependence of the relaxation modulus for the gluten-water system at various measuring times $\left(30^{\circ} \mathrm{C}\right)$.

の時間の経過とともに低下するが，その值は試料に加えた伸びひ ずみの大きさに依存しない，すなわち，微小なひずみの範囲にお いて, 試料の応力緩和現象は線形であるとみなせる。 てのてとか ら, dough について観測されるいちじるしい非線形粘弾性挙動 1),2) は, 分散相成分として多量に存在するデンプン粒子に由来す るととが明らかである。

\section{$3 \cdot 2$ 温度依存性}

Fig. 2〜4 は，それぞれグルテンー水 2 成分系標準試料，標準 試料に還元型グルタチオンを添加した系, および標準試料に電解 質を添加した系について, 応力緩和曲線の温度変化を示したもの である. 試料には水が存在すること, タンパク質は高い温度で変 性するてとなどから, 実測された温度篹国はきわめてせまいが, 前記のように試料は線形粘弾性体であると考えられるので，ての 結果に換算变数法を適用して Fig. 5 亿亦すような合成曲線を得 た. なお, 移動因子のアレニウスプロットから求められる活性化 エネルギーの值は，つぎに述べる還元型グルタチオン添加系を除 き, いずれも約 $30 \mathrm{kcal} / \mathrm{mole}$ である. グルタチオン添加系では, その值が $20^{\circ} \mathrm{C}$ 以上の温度で約 $50 \mathrm{kcal} / \mathrm{mole}$ になる。

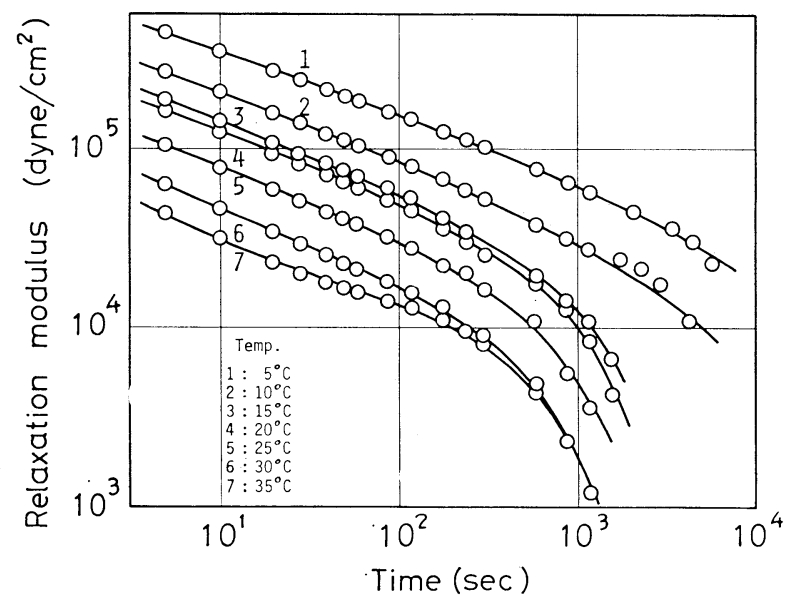

Fig. 2. Stress relaxation curve of the gluten-water system.

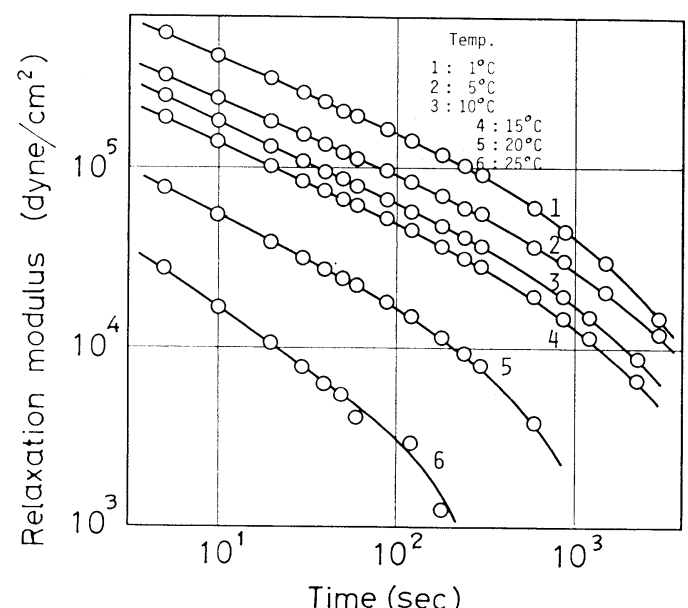

Fig. 3. Effect of reducing glutathione on the stress relaxation curve of the gluten-water system $(2 \mu$ mole glutathione/g gluten).

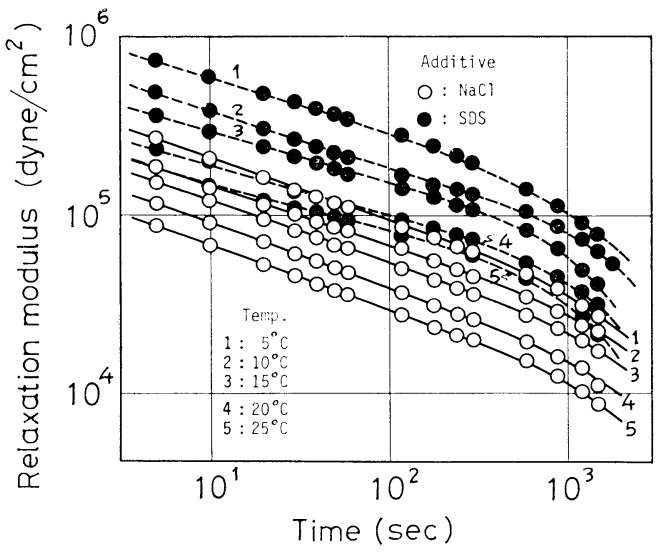

Fig. 4. Effect of sodium chloride or sodium dodecyl sulfate (SDS) on the stress relaxation curve of the gluten-water system (the sample was prepared with aq. $1 \mathrm{M} \mathrm{NaCl}$ soln. or aq. 1M SDS soln.).

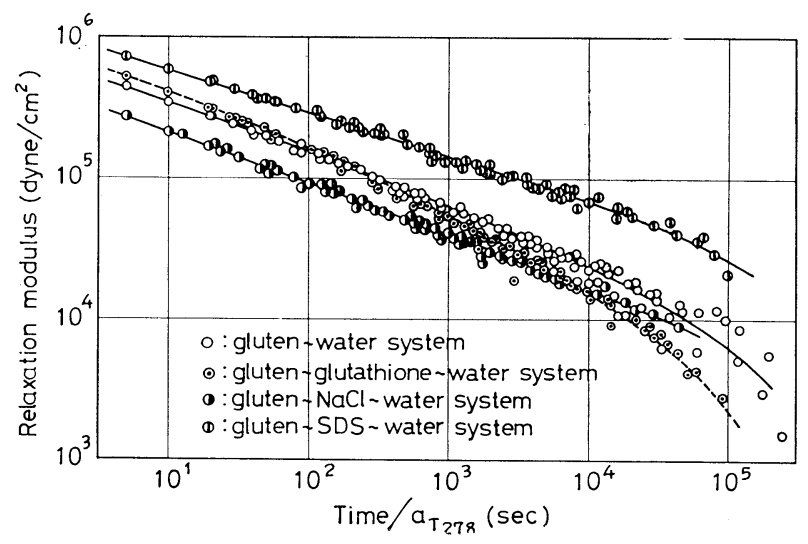

Fig. 5. Master curves for the relaxation modulus of the glutenwater systems (the reference temperature is $278^{\circ} \mathrm{K}$ ). 


\section{$3 \cdot 3$ 還元型グルタチオン添加の影響}

小麦粉の dough のレオロジー的性質が, 微量の酸化剤や還元 剤の存在により影響されることは, 既報 ${ }^{1), 2)}$ のとおりである. また，グルテンを小麦粉から分離するとグルテンのもつ-SH 基 が酸化消失するので5)，本実験の試料に酸化剤や-SH 基のブロッ ク試薬を加えてもその影響はあらわれない.しかし，還元型グル タチオンを, $1 \mathrm{~g}$ のグルテンに対し $2 \mu$ mole の割合で添加し調製 した試料は, Fig. 3 のように $20^{\circ} \mathrm{C}$ 以上の温度で無添加の試料と比 較して弾性率の低下と応力緩和の割合の増加を示すようになる. Fig. 3 の結果は, 試料温度を変化させる方向を変えても, 再現性 よく観測されるので, この現象に対しては, グルタチオンの添加 による-SS- 結合の開裂とそれにともなうグルテン分子量の低下 を考えるよりも，むしろグルテン分子間あるいは分子内の-SH基と-SS- 結合との交換反応が還元型グルタチオンの添加により 誘起され，それが $20^{\circ} \mathrm{C}$ 以上の温度で活発になる状況を考えるべき であろう。

$3 \cdot 4$ 食塩およびドデシル硫酸ナトリウム (SDS) 添加の影響 Fig. 4 亿，0.1M 食塩水および同濃度の陰イオン性界面活性剂 である SDS 水溶液を用いて調製した各試料の応力緩和曲線を示 す. 両性高分子電解質であるタンパク質は, 解離基の解離状態に 応じてその諸性質を変えるが ${ }^{6), 7)}$ ，Fig. 4 亿みられる電解質類添
加の効果や電解質の種類によるその特異性について考察を行なう ためには, さらに試料の粘弾性に対する電解質の種類やその濃度 の影響を詳細に観測することが必要である。乙の種の央験を展開 させるととにより, グルテンと電解質の相互作用に関する知見と, 製パン等の実用面における各種塩類添加の意義を明確にするため の資料が得られるものと期待される.

最後に, 本実験に熱心に協力された福田英憲氏に対し, 深く感 謝する.

（昭和48年10月23日 第21回レオロジー討論会にて講演）

$$
\text { 文献 }
$$

1）松本幸雄, 福田英憲, 米沢大造, 材料, 21，387（1972）.

2）松本幸雄, 福田英憲, 米沢大造, 材料, 22, 427 (1973).

3) Hamauzu, Z., T. Arakawa, and D. Yonezawa, Agr. Biol. Chem., 36, 1829 (1972).

4) Jones, R.W., N.W. Taylor, and F.R. Senti, Arch. Biochem. Biophys., 84, 363 (1959).

5) 岡田憲三, 米沢大造, 農芸化学雑誌, 41, 329 (1967).

6) Knox, W.J., and T.O. Parshall, J. Colloid Interface Sci., 33, 16 (1970).

7) Mita, T., E. Igucih, K. Yamada, S. Matsumoto, and D. Yonezawa, J. Texture Studies, 5, 90 (1974). 